УДК 343.985 .3

DOI 10.18101/2658-4409-2020-1-54-59

\title{
ОСОБЕННОСТИ ПОДГОТОВКИ ГОСУДАРСТВЕННОГО ОБВИНИТЕЛЯ К УЧАСТИЮ В СУДЕБНОМ РАЗБИРАТЕЛЬСТВЕ ПО УГОЛОВНЫМ ДЕЛАМ О ДОРОЖНО-ТРАНСПОРТНЫХ ПРЕСТУПЛЕНИЯХ
}

\section{() Латыпова Кристина Сергеевна}

кандидат юридических наук, доцент, Бурятский государственный университет имени Доржи Банзарова Россия, 670000, г. Улан-Удэ, ул. Сухэ-Батора, 6

E-mail: krista.100@mail.ru

Автор анализирует особенности подготовки государственного обвинителя к участию в судебном разбирательстве по уголовным делам, предусмотренным ст. 264 УК РФ. На основе изучения различных точек зрения он предлагает свой перечень (алгоритм) особенностей, на которых должен останавливаться прокурор при изучении поступивших материалов уголовных дел. Данный алгоритм учитывает особенности их рассмотрения по дорожно-транспортным преступлениям, что является актуальным и востребованным. Резюмируя рассмотренное в статье, автор приходит к выводу о необходимости прокурором в ходе подготовки к судебному процессу составлять план его действий, что повысит эффективность поддержания государственного обвинения в суде.

Ключевые слова: поддержание государственного обвинения в суде; дорожно-транспортные преступления; методика расследования; особенности подготовки к судебному разбирательству; прокурор.

\section{Для цитирования}

Латыпова К. С. Особенности подготовки государственного обвинителя к участию в судебном разбирательстве по уголовным делам о дорожнотранспортном происшествии // Вестник Бурятского государственного университета. Юриспруденция. 2020. Вып. 1. С. 54-59.

«Успех поддержания государственного обвинения, несомненно, во многом определяется качеством доследственной проверки по факту ДТП и проведенного предварительного расследования» [6, с. 653]. Таким образом, прокурору, в чьи полномочия входит поддерживание государственного обвинения при подготовке к судебному разбирательству, очень важно уделить внимание изучению материалов уголовного дела.

Для этого мы рекомендуем прокурору, которому поручено поддерживать государственное обвинение, использовать следующий алгоритм [7, c. 91]. Отметим, что авторы достаточно часто дают рекомендации к изу- 
К. C. Латыпова. Особенности подготовки государственного обвинителя к участию в судебном разбирательстве по уголовным делам...

чению материалов уголовных дел, некоторые из них предлагают для этих целей алгоритмы [3, с. 8], что, скорее всего, определяется их практической значимостью и простотой в изложении информации. Остановимся на некоторых этапах и особенностях при изучении прокурором поступающих материалов уголовных дел.

1. Изучение обвинительного заключения. До непосредственного изучения материалов уголовного дела прокурору важно удостовериться в том, что обвинительное заключение подписано следователем и утверждено прокурором; необходимо уточнить, составлено ли обвинительное заключение в соответствии с требованиями ст. 220 УПК РФ.

1.1. Приложена ли к обвинительному заключению справка:

- о сроках следствия; вещественных доказательствах; процессуальных издержках; гражданском иске, принятых мерах по обеспечению исполнения наказания в виде штрафа, по обеспечению гражданского иска и возможной конфискации имущества;

- об избранных мерах пресечения с указанием времени содержания под стражей и домашнего ареста (если таковые избирались);

- при наличии у обвиняемого, потерпевшего иждивенцев, о принятых мерах по обеспечению их прав. Необходимость в принятии таких мер чаще возникает по уголовным делам, квалифицируемым по ч. 3-6 ст. 264 УК РФ [4, с. 189].

1.2. Переведены ли обвинительное заключение, иные процессуальные документы для обвиняемого, не владеющего или недостаточно владеющего языком уголовного судопроизводства, на родной язык или на язык, которым он владеет.

1.3. Представлены ли необходимые доказательства, подтверждающие обвинение, и доказательств, на которые указывает сторона защиты, дано ли краткое описание каждого доказательства; имеются ли при описании каждого из них ссылки на тома и листы дела, точны ли они.

1.4. Указаны ли отягчающие и смягчающие наказание обстоятельства. Так, ранее нами в рамках изучения материалов уголовных дел было установлено, что в $27 \%$ случаев не все обстоятельства, смягчающие, отягчающие наказание, были отражены в обвинительном заключении. При этом в 6\% уголовных дел следователи в обвинительном заключении допускали ошибки, излагая обстоятельства, отягчающие наказание, при отсутствии таковых [5, с. 191].

2. Изучение предъявленного обвинения. Немаловажное значение имеет проверка законности и обоснованности предъявленного обвинения. В соответствии со ст. 171 УПК РФ постановление о привлечении в качестве обвиняемого желательно изучить исходя из предложенного нами ниже алгоритма. 
2.1. Верно ли указаны фамилия, имя, отчество обвиняемого, время и место его рождения. Уточняем, что важными являются такие данные о личности обвиняемого, как его фамилия, имя, отчество, дата рождения. Неправильное указание этих данных в обвинительном заключении ставит под сомнение соответствие личности обвиняемого данным о личности лица, подлежащего привлечению к уголовной ответственности за данное деяние, а также соответствие данных о личности лица, в отношении которого дело направлено в суд, - личности лица, привлеченного в качестве обвиняемого.

2.2. Правильно ли описано событие преступления с указанием места, времени его совершения.

2.3. Обоснована ли виновность лица, форма его вины и мотивы совершения преступления.

2.4. Соответствует ли формула и формулировка обвинения диспозиции соответствующей статьи (статей) УК РФ.

2.5. Не допущены ли ошибки при квалификации общественно опасного деяния. По рассматриваемой категории уголовных дел типична ситуация, когда не устанавливается такой квалифицирующий признак, как «совершение преступления в состоянии опьянения» [5, с. 194]. Исходя из этого, обращаем внимание на необходимость проверки материалов уголовного дела на предмет того, кто ранее из участников указывал на то, что обвиняемый в момент совершения ДТП находился в состоянии алкогольного опьянения, имеются ли доказательства, подтверждающие (опровергающие) показания таких лиц.

2.7. Описаны ли последствия преступления, характеристики причиненного вреда и другие обстоятельства.

\section{3. Проверка соблюдения права на защиту}

3.1. Был ли обеспечен подозреваемый, обвиняемый помощью адвоката-защитника. Не предъявлено ли обвинение в отсутствие адвокатазащитника, с которым у обвиняемого было заключено соглашение. Не допускалось ли в качестве защитника лицо, у которого истекли полномочия адвоката. Не производилась ли необоснованная замена адвокатов, допущенных в дело; отказывался ли официально обвиняемый от защитника после назначения ему новых.

3.5. Допрошен ли он в полном объеме предъявленного обвинения, в том числе по вопросам вины, мотивам, квалифицирующим признакам вменяемого преступления, по смягчающим и отягчающим наказание обстоятельствам; выяснено ли у обвиняемого его возможное алиби, проверено ли оно [5, с. 193]. 
К. C. Латыпова. Особенности подготовки государственного обвинителя к участию в судебном разбирательстве по уголовным делам...

\section{4. Проверка обеспечения прав потерпевшего}

4.1. Признано ли лицо потерпевшим в установленном законом порядке, верно ли приведены его личные данные (фамилия, имя, отчество, дата, место рождения, место жительства и пр.).

4.2. Установлены ли характер и размер вреда, причиненного потерпевшему, верно ли определена степень тяжести вреда его здоровью, достоверно ли установлено, что вред причинен именно в результате ДТП.

4.3. Разъяснены ли потерпевшему особенности рассмотрения уголовного дела судом в порядке гл. 40 УПК РФ, а также право не давать согласия на ходатайство обвиняемого о постановлении приговора без проведения судебного разбирательства (при наличии указанного ходатайства в материалах уголовного дела).

5. Взаимодействие с оперативными сотрудниками и следователем

В большинстве случаев по уголовным делам, квалифицирующимся по ст. 264 УК РФ, а также по другим преступлениям, взаимодействие прокурора со следователем при подготовке к рассмотрению дела судом зачастую требует изучения дополнительной информации с целью выработки предварительной позиции по уголовному делу; установления характера и степени противодействия со стороны защиты, иных лиц.

Взаимодействие с органами - субъектами ОРД - помимо указанного может иметь место и для целей пресечения активного, прежде всего незаконного противодействия уголовному преследованию со стороны защиты (оказание незаконного воздействия на свидетелей, потерпевших с целью изменения ими своих показаний, воздействие на должностных лиц, осуществляющих уголовное преследование и пр.) [1, с. 67].

В процессе изучения материалов уголовного дела и дополнительных материалов прокурор, на которого возложены функции по поддержанию государственного обвинения, формирует предварительную позицию по уголовному делу. «Уровень поддержания обвинения в суде определяется не только знанием и правильным исполнением уголовно-процессуальных норм, но и в значительной степени умелым использованием криминалистических приемов и методов» $[4$, с. 5$]$.

Рассмотренное выше подтверждает выводы о том, что прокурор при подготовке к судебному заседанию должен заранее прогнозировать возможные ситуации, которые могут возникнуть в ходе рассмотрения уголовного дела в судебном разбирательстве и планировать свои действия по поддержанию государственного обвинения заблаговременно.

Таким образом, в некоторых субъектах России регламентирована обязанность прокуроров планировать свое участию в суде по уголовному делу, который должен включать в себя событие, полноту доказательств, выявленные процессуальные ошибки следствия, количество и сущность 
возможных ходатайств, направления и последовательность исследования доказательств, участие в следственных действиях и преодоление противодействия стороны защиты [2, с. 152]. Резюмируя вышесказанное, считаем, что составление плана, включающего указанный перечень, даст возможность быстро и эффективно подготовиться к рассмотрению уголовного дела в суде по данной категории уголовных дел.

\section{Литература}

1. Александров А. С., Кухта А. А., Абдуллаев Я. Д. Оперативное сопровождение поддержания государственного обвинения в суде // Практическое законоискусство. 2007. № 1. С. 61-70.

2. Вдовин А. Н. Особенности методики расследования и поддержания государственного обвинения по уголовным делам о преступлениях, связанных с незаконным оборотом оружия и боеприпасов (по материалам приграничных регионов Сибирского федерального округа): дис. ... канд. юр. наук. Новосибирск, 2015. С. 152.

3. Кириллова А. А. Алгоритм изучения и критерии оценки материалов уголовного дела // Краткое руководство по судебному разбирательству уголовных дел об убийствах, предусмотренных ч. 1 ст.105 УК РФ: практ. пособие. М., 2015. С. 80.

4. Кисленко И. Л. Криминалистические основы поддержания государственного обвинения: дис. ... канд. юр. наук. Саратов, 2010. С. 5.

5. Латыпова К.С. Особенности методики расследования и поддержания государственного обвинения по уголовным делам о нарушениях правил дорожного движения и эксплуатации транспортных средств, связанных с наездами на пешеходов: дис. ... канд. юр. наук. Улан-У дэ, 2017. 217 с.

6. Руководство для государственного обвинителя: учеб. пособие / под ред. О. Н. Коршуновой. 3-е изд., испр. и доп. СПб., 2015. 732 с.

7. Руководство для следователя и его общественного помощника: учеб.-практ. пособие / под общ. ред. Ю. П. Гармаева. М., 2010. С. 91. 
K. C. Латыпова. Особенности подготовки государственного обвинителя к участию в судебном разбирательстве по уголовным делам...

PECULARITIES OF PREPARING A STATE ACCOUNTANT TO PARTICIPATE IN JUDICIAL PROCEEDINGS ON CRIMINAL DETAILS ON ROAD TRANSPORT CRIMES

\section{Kristina S. Latypova}

Cand. Sci. (Law), A/Prof.,

Dorzhi Banzarov Buryat State University

6 Sukhe-Batora St., Ulan-Ude 670000, Russia

E-mail: krista.100@mail.ru

The author analyzes the peculiarities of preparing a public Prosecutor to participate in criminal proceedings under article 264 of the criminal code of the Russian Federation. Based on the study of various points of view, it offers its own list (algorithm) of features that the Prosecutor should focus on when studying the received materials of criminal cases. This algorithm takes into account the peculiarities of their consideration for road traffic crimes, which is relevant and in demand. Summarizing the issues discussed in the article, the author comes to the conclusion that the Prosecutor needs to draw up a plan of actions during the preparation for the trial, which will increase the effectiveness of maintaining the state prosecution in court.

Keywords: support of the state prosecution in court; traffic crimes; investigation methodology; peculiarities of preparation for trial; Prosecutor. 